\title{
Use of fish embryo biomarkers for the evaluation of mazut toxicity in marine environment
}

\author{
Irina Ivanovna Rudneva $(\mathbb{D}$
}

Received: 29 January 2019/Accepted: 8 April 2019/Published online: 23 April 2019

(C) The Author(s) 2019

\begin{abstract}
The risk of oil contamination, either through produced water discharges, accidents, or non-pointsources, has increased, and it is attributed with the negative impact on the Black Sea ecosystem, and especially in coastal waters. Coastal marine waters are known as the areas of fish and invertebrates spawning sites, including commercial species, which early developmental stages are highly sensitive to crude oil and its derivates. The aim of the present study was to investigate the effects of mazut at concentrations of 0.00001 , $0.0001,0.001,0.01,0.1$, and $1 \mathrm{ml} \mathrm{l}^{-1}$ on the biomarker response in the developmental embryos (stages IV and V) of tubenose goby Proterorhinus marmoratus. We used the biomarkers of antioxidant enzyme activities, namely superoxide dismutase (SOD), catalase (CAT), peroxidase (PER) and glutathione reductase (GR). The non-uniform response on mazut impact at tested concentrations on fish embryos was shown. The best biomarker was peroxidase activity, which was highly sensitive to oil pollution and reflected the response of the organism on stressful environment. The imbalance between tested antioxidant enzyme activities was clearer at low and high levels of mazut, and it was less in the case of medium values. The obtained results can be applied for the development of oil toxicity tests for monitoring management and for perspectives of conservation ecology.
\end{abstract}

Keywords Black Sea · Oil pollution · Tubenose goby Proterorhinus marmoratus · Antioxidant enzymes

\section{Introduction}

Usually, the investigators report the elevated levels of the man-made pollution and its deleterious effects on marine environment and aquatic organisms in all levels of their biological organization. Sewage and hazard chemicals from industrial, agricultural, maritime transport and domestic effluents are the main sources of contamination in the Black Sea ecosystem. Coastal waters are the main recipients of discharges, and combine effects of the various kinds of toxicants result in dramatic ecological consequences such as eutrophication, biodiversity loss, elimination of some species, worsening of their health and decline in the population size (Rudneva and Petzold-Bradley 2001; Oguz 2017). The risk of oil contamination, either through produced water discharges, accidents, or non-point-sources, has increased, and it is accompanied with the negative impact on marine ecosystems, sometimes resulting in extreme consequences for the marine environment, characterizing physical, chemical and biological damage of the water, sediments and impacted natural resources. Besides that, the Eastern Mediterranean and the Black Sea along with Bosphorus and Dardanelles

I. I. Rudneva ( $\square)$

A.O. Kovalevski Institute of Marine Biological Research, Russian Academy of Sciences, Sevastopol, Russian Federation e-mail:svg-41@mail.ru 
straits are located along a heavy oil traffic and the important accidents in recent decades really take place in this region (Çokacar 2008; Florin et al. 2015; Carpenter and Kostianoy 2019). Moreover, the increasing of shipboard transport of petroleum products, consequently, ship operation, oil drilling, pipe cracks and transport of bunker fuel have the risk of oil spills (Patin 2015; Oguz 2017; Sardi et al. 2017). In the Black Sea alone, oil production has been increased, it was estimated that annually 80-130,000 tons of oil enters the ecosystem, and $1 \%$ of this is associated with the accidents (Leonov and Fashuk 2006). Therefore, the study of the consequences of oil pollution in the Black Sea and especially in its coastal waters is an important problem for the evaluation of the ecological status of the marine ecosystem, because petroleum contamination is chronic in the Black Sea. Oil is distributed in the water and accumulated in bottom sediments and biota. In future, petroleum pollution in the shelf zone of the sea will rise intensively, and so the risk of oil spills (Kuznetsov and Fedorov 2010).

On the other hand, marine coastal ecosystems are known as the spawning areas of many commercial fish and invertebrate species. Early developmental stages of them are very sensitive to pollution, including oil and its derivates. Previously, the researchers have reported the negative impact of oil contamination on fish eggs and larvae (Rudneva 2014; Mu et al. 2018; Pereira et al. 2018; Hansen et al. 2018). Oil induced a series of abnormalities during fish embryonic development, increased embryo mortality at various stages, changed the morphogenesis and organ formation, and modified the responses of the defense antioxidant and immune systems (Pauka et al. 2011; Mu et al. 2018; de Andrade et al. 2018).

Fish biochemical parameters could be directly related to the area, where the fish were collected. In polluted sites, the exposure of fish to xenobiotics results in the interaction between these chemicals and biological systems, which may give rise to biochemical and physiological damage or/and adaptive mechanisms via the induction of defense immune and antioxidant systems. Therefore, biochemical and physiological parameters are used as biomarkers for contaminants and could be applied to evaluate environmental stress and its aftereffects in aquatic organisms. Biomarker exposure to environmental stressors varies widely depending on the type of anthropogenic activity involved. In this context, a series of studies have determined levels of antioxidant biomarkers and assessed their response to crude oil and its derivates in fish and invertebrates in field and experimental conditions (Van der Oost et al. 2003). The toxicity is associated with the growth of ROS (reactive oxygen species) generation, resulting in the imbalance of oxidative and pro-oxidative processes in the organism, pathological changes, diseases and, finally, death (Lesser 2006).

Antioxidant enzymes are known as adequate biomarkers for oxidative stress, which is induced by many unfavorable factors. Antioxidant enzyme activities in various tissues and organs of aquatic organisms and their changes are good biomarkers for the organism status in the unfavorable living conditions, and they are used successfully as tools for biomonitoring. The researchers reported the fluctuations of antioxidant enzyme activities in the tissues of marine organisms indicated that they inhabited polluted sites or impacted different toxicants in experimental conditions (Sarkar et al. 2006; Rudneva 2014; Mu et al. 2018). However, it is necessary to establish a causality between measurable changes in biomarkers and contamination level both from laboratory bioassays and in the field conditions (Depledge and Galloway 2015; Sardi et al. 2017). On the other hand, the information of the biomarker response in early life of the aquatic organisms is scarce despite many of them being used in national and international monitoring programs for the evaluation of the water quality of the ecosystems, including the consequences after oil accidents and spills (Martinez-Gomez et al. 2006; Van der Oost et al. 2003). In the case of the Black Sea, we could propose that intensive exploitation and transport of oil and its derivatives are increasing the risk of coastal water and sediment contamination by either dramatic disasters or diffuse sources. Tools for monitoring diffuse contamination, such as crude oil and its fractions that leak from marine vessels, are much needed.

The aim of the present study was to investigate the response of antioxidant enzyme activities in tubenose goby Proterorhinus marmoratus embryos (stages IV and V) treated by mazut at the concentrations of 0.00001 , $0.0001,0.001,0.01,0.1$, and $1 \mathrm{ml}^{-1}$. For assessment of multiple biomarker responses in fish eggs, we determined the biomarkers of exposure, used antioxidant level in the form of enzymes activity that reflects the response to the toxicity of reactive oxygen species (ROS): superoxide dismutase (SOD), catalase (CAT), peroxidase (PER), and glutathione reductase (GR). 


\section{Materials and methods}

Fish egg collection

Tubenose goby Proterorhinus marmoratus is a benthic fish, which is distributed in the basins of Black Sea, the Sea of Azov, Marmara Sea, Caspian Sea and in the northern part of Aegean Sea. Spawning time covers the period from April to June; the spawning process occurs at the depth of 10-80 $\mathrm{cm}$. Individual female spawns from 200 to 1000 eggs. Maturation begins at the age of 2 years, lifespan continues 2-3 years. It is abundant at shell rock and seagrass biotopes. It is usually found in Sevastopol bays and estuaries (Rudneva et al. 2016). Eggs were obtained in field conditions in Streletskaya Bay (Black Sea), at the coastal line of the city of Sevastopol (Crimea) at the spawning time in May-June.

After collection, the eggs were immediately placed in the aerated tank and transfer to the laboratory. The eggs at the stages IV and V were incubated at +12.5 to $13{ }^{\circ} \mathrm{C}$ at different concentrations of mazut. Morphological characteristics of the embryos are presented in Table 1.

Preparation of mazut solutions

Mazut (black mineral oil) is a heavy, low-quality fuel oil used in generating plants and similar applications. It may be used as an energy fuel for heating houses and for ships. For experimental purposes, in our study, mazut was mixed at the concentrations of $0.00001,0.0001,0.001,0.01,0.1$, and $1 \mathrm{ml}^{-1}$ in the filtrated marine water (the Black Sea, salinity $18 \mathrm{~g} \mathrm{l}^{-1}$ ), and the mixtures were stripped using magnetic stirrer for 20-30 min, and after 30 min the mixture was used in experiments (Chesalina et al. 2000).

\section{Experimental design}

Test emulsions of mazut with the concentrations of 0 (control), 0.00001, 0.0001, 0.001, 0.01, 0.1 and $1 \mathrm{ml} 1^{-1}$ were made using filtrated marine water. 50 embryos in stages of IV and V were randomly transferred into test solutions in aerated tanks of the volume 1.5 1. Each treatment was replicated three times. At the end of the tested developmental stage ( $68 \mathrm{~h}$ at the case of stage IV and $98 \mathrm{~h}$ at the case of stage $\mathrm{V}$ ) the living embryos were homogenized in cold $0.85 \% \mathrm{NaCl}$ using glass homogenizer, and the homogenates were centrifuged at $8000 \mathrm{~g} 15 \mathrm{~min}$ at cool conditions. The supernatants were used for biochemical determinations.

\section{Biochemical assays}

Antioxidant enzyme activities in the supernatants were determined according to the methods described previously (Rudneva 1999), with a few minor modifications. The activity of superoxide dismutase (SOD) was assayed on the basis of inhibition of the reduction of nitroblue tetrazolium (NBT) with NADH mediated by phenazine methosulfate (PMS) under basic conditions (Nishikimi et al. 1972). All measurements were performed in $0.017 \mathrm{M}$ sodium pyrophosphate buffer, $\mathrm{pH} 8.3$, at $+25^{\circ} \mathrm{C}$. The reaction mixtures contained $5 \mu \mathrm{M}$ NBT, $78 \mu \mathrm{M}$ NADH, $3.1 \mu \mathrm{M}$ PMS, and a $0.1 \mathrm{ml}$ sample; the final volume was $1.5 \mathrm{ml}$. The reaction was carried out in a spectrophotometer (Carl Zeiss, Jena, Germany) at $560 \mathrm{~nm}$. The enzyme activities were calculated as arbitrary units $\mathrm{U}$ per ( $\mathrm{min} \mathrm{mg}$ protein $)^{-1}$. Catalase (CAT) activity was measured by the method involving the reaction of hydroperoxide reduction (Asatiani 1965). The enzyme activities were calculated in

Table 1 Morphological characteristics of the tested goby embryos (Dechnik 1973; Kalinina 1976)

\begin{tabular}{lll}
\hline $\begin{array}{l}\text { Stage of embryonic } \\
\text { development }\end{array}$ & $\begin{array}{l}\text { Time of } \\
\text { development, h }\end{array}$ & Morphological characteristics of embryo development \\
\hline Stage IV & $68-74$ & $\begin{array}{l}\text { The formation of embryonic strip, head, neural system, chorda, brain bladders, } \\
\text { eyecup, the beginning of body segments and ear capsules } \\
\text { Growth of the tail, the separation of the tail from the egg yolk. The formation of the } \\
\text { hart, gut, liver and the fin formation }\end{array}$ \\
Stage V & $98-104$ &
\end{tabular}


mmol per (min mg protein) $)^{-1}$. Peroxidase (PER) activity was detected by a spectrophotometric method using benzidine reagent (Litvin 1981). The reaction mixture contained $1 \mathrm{ml}$ acetate buffer, $\mathrm{pH} 5.4,0.4 \mathrm{ml} 0.09 \%$ benzidine, $0.2 \mathrm{ml} 0.03 \% \mathrm{H}_{2} \mathrm{O}_{2}$, and $0.2 \mathrm{ml}$ sample. The reaction was followed in a spectrophotometer for $1 \mathrm{~min}$ at $20{ }^{\circ} \mathrm{C}$ and at $600 \mathrm{~nm}$. The enzyme activities were calculated in optical units U per (min mg protein $)^{-1}$. Glutathione reductase (GR) activity was assayed spectrophotometrically using a method modified after Pereslegina (1989). The reaction mixture contained $0.1 \mathrm{ml} \mathrm{mM} \mathrm{NADPH,} 0.5 \mathrm{ml} 7.5 \mathrm{mM}$ oxidized glutathione, $0.2 \mathrm{ml} \mathrm{mM}$ EDTA, and $2 \mathrm{ml} 0.05 \mathrm{M}$ phosphate buffer, $\mathrm{pH}$ 8.0. After incubation for $10 \mathrm{~min}$, the extinction of the mixture was determined at $340 \mathrm{~nm}$. The enzyme activities were calculated in $\mathrm{nmol} \mathrm{NADH}$ per (min mg protein $)^{-1}$. Total soluble protein concentration was quantified spectrophotometrically using the method of Lowry et al. (1951). The enzyme activities were calculated in mmol or specific units U $(\text { min } \mathrm{mg} \text { protein })^{-1}$.

Statistical analysis

Biochemical measurements were detected in duplicate for each sample. Simple, descriptive statistics were performed using an ANOVA (Halafian 2008). $P$ value of 0.05 was used for the determination of statistical significance between control values and the values of individual experimental group. Statistical analyses were performed using Statistica software. The differences in the levels of antioxidant enzyme activities in the eggs and the mazut concentrations among the sampling points were examined by post hoc test. Statistical correlations between studied biochemical parameters and mazut concentrations in tested experimental groups were calculated by the least-squares method using the computer program CURVEFIT (Version 2.10-L). The graphs were constructed using Microsoft Office Excel software.

\section{Results}

The activity of studied antioxidant enzymes in the developing fish embryos exposed to different concentrations of mazut fluctuated non-uniformly (Fig. 1).

In stage IV embryos, SOD activity varied insignificantly at all tested concentrations $(-63 /+76 \%$ to the control) with the exception of the mazut concentration of $0.1 \mathrm{ml} \mathrm{l}^{-1}$, when the enzyme level elevated $658 \%$ as compared with the control ( $p<0.05$, Fig. 1). No significant differences were observed in stage V embryos, and enzyme activity ranged between -17 and $-82 \%$ in all experimental groups as compared with the control. However, the activity was significantly decreased at the concentration of $0.01 \mathrm{ml} \mathrm{l}^{-1}$ (more than fivefold, $p<0.05)$. We could mark also that in stage $\mathrm{V}$ embryos, the trend of enzyme activities in low mazut concentrations $\left(0.00001-0.01 \mathrm{ml} \mathrm{l}^{-1}\right)$ was similar to the fluctuations of SOD level in the egg in stage IV.

CAT activity in stage IV embryos ranged insignificantly between -70 and $+87 \%$ as compared with the values of the intact group. The highest enzyme level in stage $\mathrm{V}$ embryos was indicated at the mazut concentration of $0.0001 \mathrm{ml} \mathrm{l}^{-1}(+416 \%$ to the control, $p<0.05)$; in other experimental groups, CAT level varied insignificantly from -39 to $+76 \%$ compared to the control. The trends of enzyme activity in stage IV and $\mathrm{V}$ embryos were similar, as we described above for the case of SOD activity.

At all tested mazut concentrations, PER activity in the embryos of stage IV was significantly higher $(+247 /+511 \%, p<0.05)$ as compared with the intact eggs, with the exception of the embryos exposed at the concentration of $0.00011 \mathrm{ml} \mathrm{l}^{-1}(+56 \%)$ and $1 \mathrm{ml} \mathrm{l}^{-1}$, when enzyme activity reduced significantly $(-95 \%, p<0.05$ to the control). PER activity in stage $\mathrm{V}$ embryos was higher at all examined mazut concentrations as compared with the control $(+103 /+1058 \%, p<0.05)$.

The response of GR activity was not uniform; in stage IV embryos, the enzyme level was increased at mazut concentrations of $0.0001 \mathrm{ml} \mathrm{l}^{-1}$ and $0.1 \mathrm{ml} \mathrm{l}^{-1}(+137 \%$ and $+110 \%$ correspondingly, $p<0.05)$, at the other tested concentrations, GR activity was insignificantly lower as compared with the control $(-6 \% /-80 \%)$. In stage $\mathrm{V}$ embryos, GR activity was increased significantly at the concentrations of $0.00001 \mathrm{ml} \mathrm{l}^{-1}$ and $1 \mathrm{ml} \mathrm{l}^{-1}(+189 \%$ and $+346 \%$, respectively, $p<0.05)$, while at the other tested mazut levels, it was lower as compared with the control (from -81 to $-31 \%$ ).

The ratios of examined enzymes activities and their fluctuations at different mazut concentrations in both the tested stages of embryo development are presented in Fig. 2. 

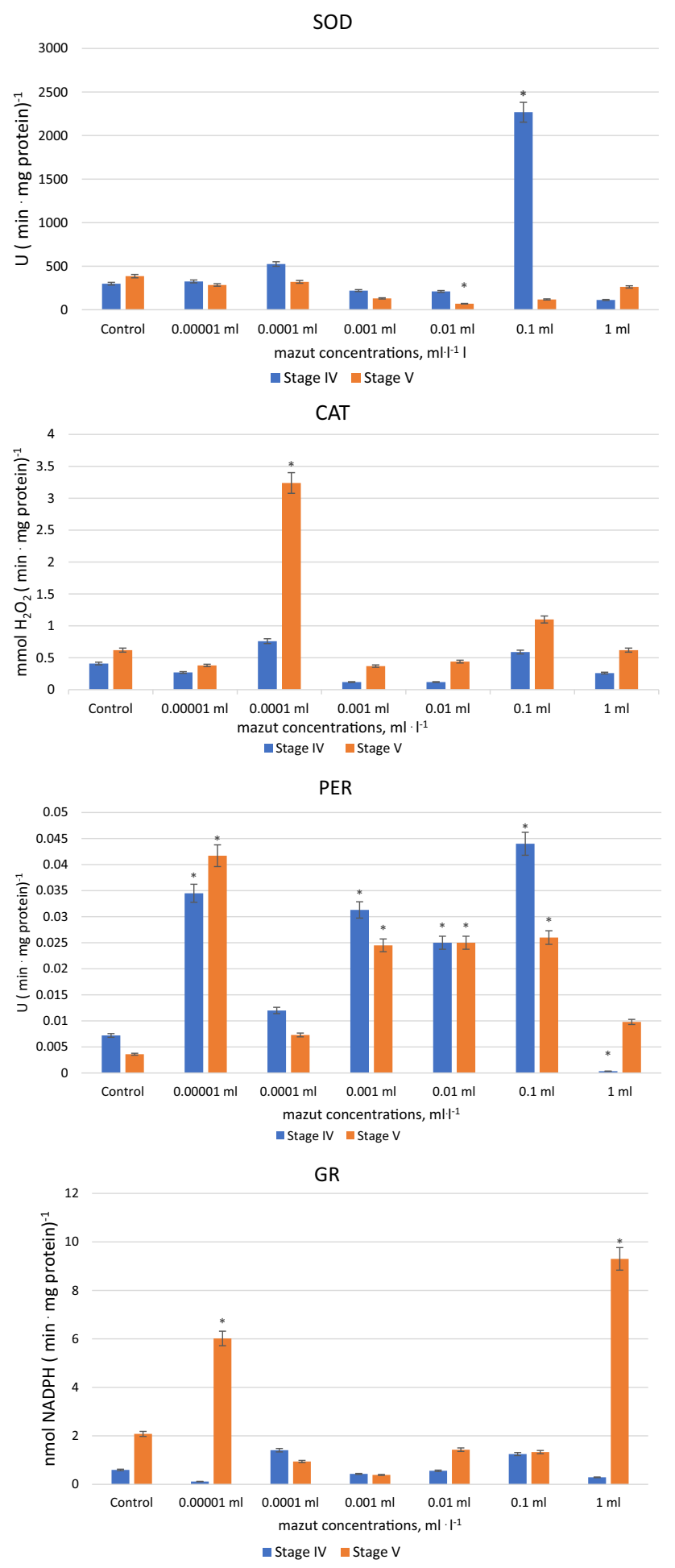

Fig. 1 Antioxidant enzyme activities in developing fish embryos Proterorhinus marmoratus exposed to different concentrations of mazut. SOD superoxide dismutase, $C A T$ catalase, $P E R$ peroxidase, $G R$ glutathione reductase. Enzyme activity is represented as $(\min \mathrm{mg} \text { protein })^{-1}$, mean $\pm \mathrm{SD}$. Asterisk: the differences are significant as compared with the control

High imbalance of the ratio SOD/CAT activity was indicated in stage IV embryos exposed to low mazut concentration of $0.00001 \mathrm{ml}^{-1}$, then the ratios declined and varied less. In stage V embryos, the ratio SOD/ CAT fluctuated insignificantly at tested mazut levels. The ratio SOD/PER demonstrated similar trends in both 

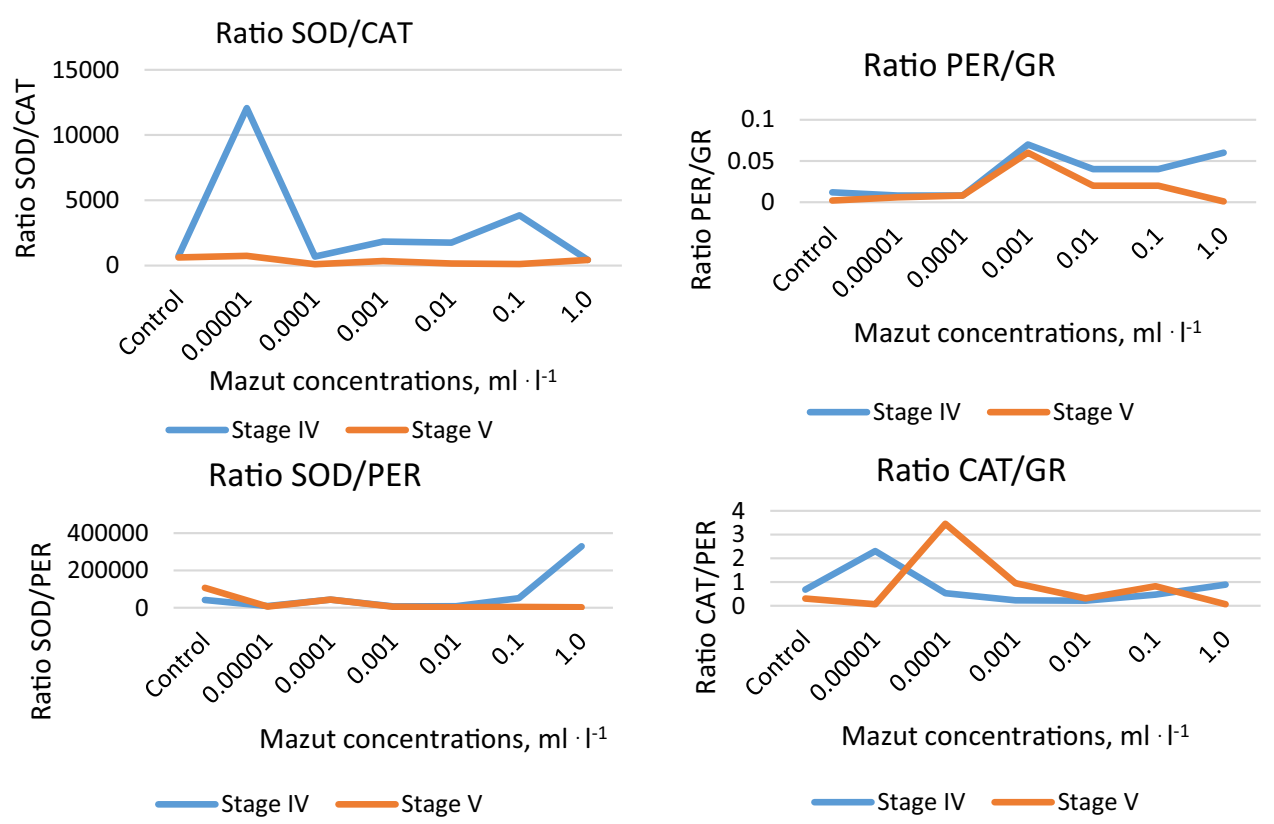

Ratio SOD/GR

Ratio CAT/PER
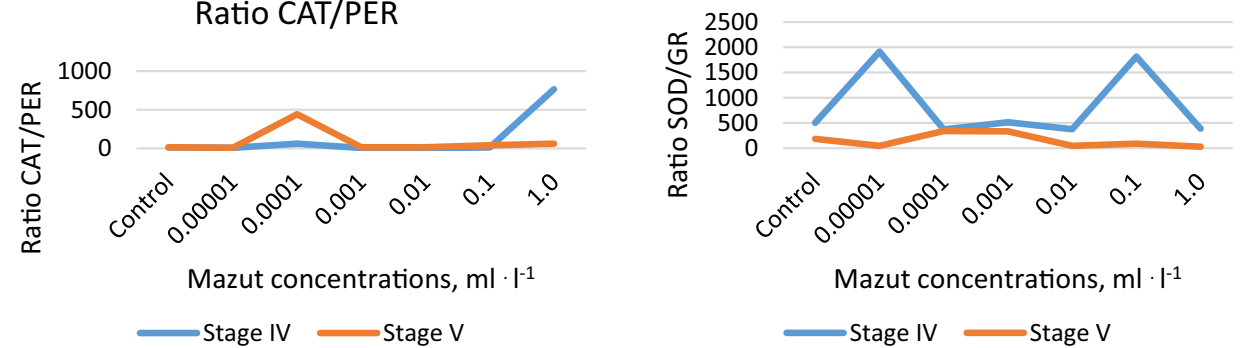

Fig. 2 Antioxidant enzyme activity ratios in developing fish embryos Proterorhinus marmoratus exposed to different concentrations of mazut. For other explanations, see Fig. 1

the embryonic stages; however, at high concentration of oil $\left(1 \mathrm{ml} \mathrm{l}^{-1}\right)$, it increased. The values of SOD/GR ratio had two peaks for stage IV embryos exposed to the concentrations $0.00001 \mathrm{ml} \mathrm{l}^{-1}$ and $0.1 \mathrm{ml}^{-1}$, while the fluctuations of the enzyme ratio in stage $\mathrm{V}$ embryos were insignificant. The highest value of CAT/PER ratio was observed in stage IV embryos treated with $1 \mathrm{ml}^{-1}$, and in stage $\mathrm{V}$ embryos exposed to $0.0001 \mathrm{ml} \mathrm{l}^{-1}$. The CAT/GR ratio was increased at low mazut concentrations of 0.00001 and $0.0001 \mathrm{ml} \mathrm{l}^{-1}$ in stage IV and $0.0001 \mathrm{ml} \mathrm{l}^{-1}$ in the case of stage $\mathrm{V}$. The trends of PER/GR ratio were similar in stage IV and V embryos with the exception of the values of the eggs exposed to the highest mazut level $\left(1 \mathrm{ml} \mathrm{l}^{-1}\right)$. In the case of stage IV, it was increased, while in stage V, the trend showed the opposite tendency.

Therefore, the obtained results demonstrated the responses of antioxidant enzymes in the goby embryos in stages IV and V to the tested concentrations of mazut. The responses were not uniform, and they depended on the toxicant level and the developmental stage of the fish embryos. Additionally, the balance between the examined enzyme activities also varied, which could be connected with the imbalance between ROS production and antioxidant defense status.

\section{Discussion}

Aquatic organism embryo tests have been used in hazard assessments of different kinds of unfavorable factors successfully because they are highly sensitive to hazardous chemicals. The sensitivity of early developmental stages to various pollutants has been frequently reported for many aquatic animals, such as sea urchins, 
bivalves, corals and fish species (Bellas et al. 2005; Farina et al. 2008; Cao et al. 2010; Rudneva 2014). Because oil spills and other accidents are frequent events in marine environment, the development of the corresponding tests for the evaluation of their consequences for the aquatic biota is very important (Heintz et al. 1999; Pereira et al. 2018). Although oil and its derivatives are widely used in human activity, and they are highly distributed pollutants in aquatic environment, the information of their toxic effects on marine organisms is yet scarce and contradictory (Martin et al. 2014; Hansen et al. 2018). For this, in experimental conditions, various test organisms are used, including early developmental stages of marine fish and invertebrates (Franco et al. 2018). Fish embryo testing in ecotoxicological studies has been largely utilized as a good tool for the toxicity assays. Zebrafish (Danio rerio) embryos are well known as a good model for toxicity assessment. They were also investigated for assessing oil toxicity. For instance, they were used for the evaluation of the potential toxicological differences between unrefined crude and residual fuel oils, and test the effects of sunlight as an additional stressor (Domingyes et al. 2010; Martin et al. 2014). Studies have been performed using the different life stages of Japanese medaka (Oryzias latipes), fathead minnow (Pimephales promelas), goldfish (Carassius auratus), rainbow trout (Oncorhynchus mykiss), etc. The life cycle stages of fish (through the embryo-larval stage) may represent a way to establish definitive testing strategies and will provide another option for the acute testing of juvenile and adult fish (Heintz et al. 1999; Embry et al. 2010; de Andrade et al. 2018).

Embryos and larvae have important roles in the life cycle of marine organisms as during this phase there are dramatic morphological and physiological changes that lead to the adult form. Despite their importance, data concerning the toxicity of pollutants in fish eggs and larvae are yet scarce. In the present study, we used as the test organism the embryos of benthic fish tubenose goby Proterorhinus marmoratus, which is highly distributed in the basins of Black Sea, the Sea of Azov, Marmara Sea, Caspian Sea and in the northern part of Aegean Sea. It inhabits coastal waters, its eggs are demersal, and they are impacted to various pollutants, including oil and its derivates (Rudneva et al. 2016). Taking into account that the oil and gas production in the shelf of these water bodies is intensively exploited (Çokacar 2008; Florin et al. 2015; Carpenter and Kostianoy 2019), the early life stages of this fish could be used as a good model for the oil toxicity effect evaluation both in natural and laboratory conditions.

Many investigators reported that the oil pollution of marine environment induces multiplicative stress in marine organisms, which is accompanied with the generation of ROS (reactive oxygen species) (Mu et al. 2013, 2018; Rudneva 2014). The toxicity of oil fractions and its derivates differed, and the response of fish in early life stages also varied and depended on experimental duration, species peculiarities, toxicant concentration, etc. There are several studies of oil effects on adult fish using the battery of biomarkers, while the information of the response of early life stages of fish and invertebrates is limited. Generally, the investigators describe the hatching process, mortality and abnormalities of development of the embryos and larvae exposed to oil and the values of these end points are discussed (Pauka et al. 2011; Martin et al. 2014).

Because mazut is used as a fuel in maritime transport, it contaminates marine environment and damages it; although that part of the oil is evaporated, the other one degrades resulting in photochemical reactions and microbial activity (Geraudie et al. 2016; Sardi et al. 2017). In the present study, our findings have shown that in fish embryos exposed to different mazut concentrations, oxidative stress has been induced, which revealed the changes of antioxidant enzyme activities in the treated groups as compared with the intact embryos. The most sensitive enzyme was PER, which activity elevated more than $100 \%$ compared to the control (103-1058\%). Generally, the trends of enzyme fluctuations were similar in both the tested fish embryo stages. The enzyme level tended to increase at low concentrations and decreased at the highest concentration of mazut, which explained enzyme inhibition, especially in stage IV embryos. However, enzyme activity in stage $\mathrm{V}$ embryos remained higher as compared with intact eggs at the mazut concentration of $1 \mathrm{ml} \mathrm{l}^{-1}$ Additionally, we could note that PER plays a role in the processes of eggshell function, because one of its componentovoperoxidase-was detected in fish eggs and it uses $\mathrm{H}_{2} \mathrm{O}_{2}$ as substrate which is generated in NADPH oxidase system on the surface of eggshell. Superoxide anion and other metabolites containing tyrosine cation are formed during the process of egg development, and they are degraded by ovoperoxidase which protects the embryos against ROS damage (Rudneva 2014). Therefore, PER was the most sensitive enzyme to mazut toxicity.

The activity of other tested enzymes varied lesser and the fluctuations were not uniform. We could note a decrease in activity of all tested enzymes at the highest mazut concentration $\left(1 \mathrm{ml} \mathrm{l}^{-1}\right)$ in both stages of goby 
embryogenesis with the exception of GR and PER activities in stage V, which was connected with the strong damage of the antioxidant defense and imbalance between oxidative and antioxidant processes, impacted by toxicant. We did not find any correlations between antioxidant enzyme activities and mazut concentration. Furthermore, we could propose that no linear correlations are present. Additionally, we could note that energetic resources of developing embryos on examined stages of development were involved for the first time in organ formation and growth (see Table 1), and the lack of energy for the synthesis of the components of defense systems resulted in poor response of the antioxidants to oil treatment. However, at high concentrations of mazut, the inhibition of majority of antioxidant enzyme activity in stage IV was observed, while in stage V, PER and GR activities were increased, perhaps it was connected with the metabolism change and increased synthesis of the components of defense system before hatching.

Additionally, we could conclude that the oxidative stress stimulated not only the changes in enzyme activities in developing fish embryos, but also the imbalance of their ratios, which is shown in Fig. 2. This imbalance was clearer at low and high levels of the oil and it was less in the case of medium values. Therefore, we could propose that low concentrations of mazut initiated the antioxidant defense, at the medium toxicant values the response was relatively stable, and at high concentrations, it was greater which also caused the inhibition of the enzyme activities and dissociation of interactions between them.

In our previous studies, we used various several Black Sea fish species in their early developmental life stages as a model for ecotoxicological experiments for the assessment of different kinds of oil toxicity, namely Neogobius melanostomus, Lypophys pavo, Atherina hepsetus, Liza saliens, Liza aurata (Rudneva 2014). The response of antioxidant system depended strongly on kinds of oil components, their concentrations and time of exposure (from 1 to 3 days of exposition in our previous experiments). We showed also that fish larvae were more sensitive than embryos. The response of embryos depended on eggshell thickness: high thickness of shell protects the developing embryo against toxic impact of oil and the response of antioxidant enzyme activities was less sensitive as compared with the embryos with thin eggshell; and fish species individual peculiarities (Rudneva 2014).

The present data agree with the results of other authors who studied oil toxic effects using fish in their early developmental stage as a model. For instance, the experimental studies of Carassius auratus eggs exposed to the water-soluble fraction of diesel at concentrations of 0.05 and $0.1 \mathrm{mg} \mathrm{l}^{-1}$ during a period of 40 days showed the induction of antioxidant enzyme activities and decreased immune reactions in the tissues of the fish (Zhang et al. 2004), and in invertebrates, the neurotoxic response was observed (Geraudie et al. 2016). The induction of antioxidant enzymes SOD, CAT and GST was demonstrated in the mollusks, exposed to water-soluble fraction of diesel fuel at a concentration of $4 \mathrm{mg} \mathrm{l}^{-1} 1$ (Jiang et al. 2017). The authors found the decrease of hatching rate and the increase of mortality of the larvae, and high mortality of embryos exposed to high oil concentrations $\left(20-40 \mathrm{mg}^{-1}\right.$ ). The hepatopancreas of the crabs had elevated levels of oxidative stress and a higher abundance of blister cells, which play a role in secretory processes. Crude oil is likely to impact fiddler crabs and many species that depend on them for their diet or for the ecological changes that result from their burrowing (Franco et al. 2018).

Finally, we could propose the following scheme of the oil (mazut) impact on fish eggs (Fig. 3). Oil changes the marine environment and impacts the early developmental stages of aquatic animals directly and indirectly, through the changing environment. In both cases, the high generation of ROS provokes oxidative stress in the organism (Lesser 2006) and modifies the oxidant/antioxidant ratio, for the first time caused antioxidant enzyme activity, as we see in our study. This is the "early warning" response of the organism on the toxic impact and it can differ depended on developing stage, species, and toxicant concentration.

The ecological characterization of the coastal waters of Sevastopol city showed the presence of diverse contaminants in the sediments and in water, which are the result of human activities. The main anthropogenic sources of these pollutants are attributed to industrial and agricultural discharges, domestic effluents, shipping and recreation activities. High concentration of xenobiotics, including oil and its derivates in the bottom sediments and in the water in the spawning area of fish, causes oxidative stress in their early life stages resulting in their transfer via water. Ecotoxicological studies of oil toxicity both in laboratory and field conditions using fish eggs as a model suggest that this mode of action should be considered in the assessment of bunker oil spill impacts, and indicate the need for a broader approach to understand the aquatic toxicity of different oils. 


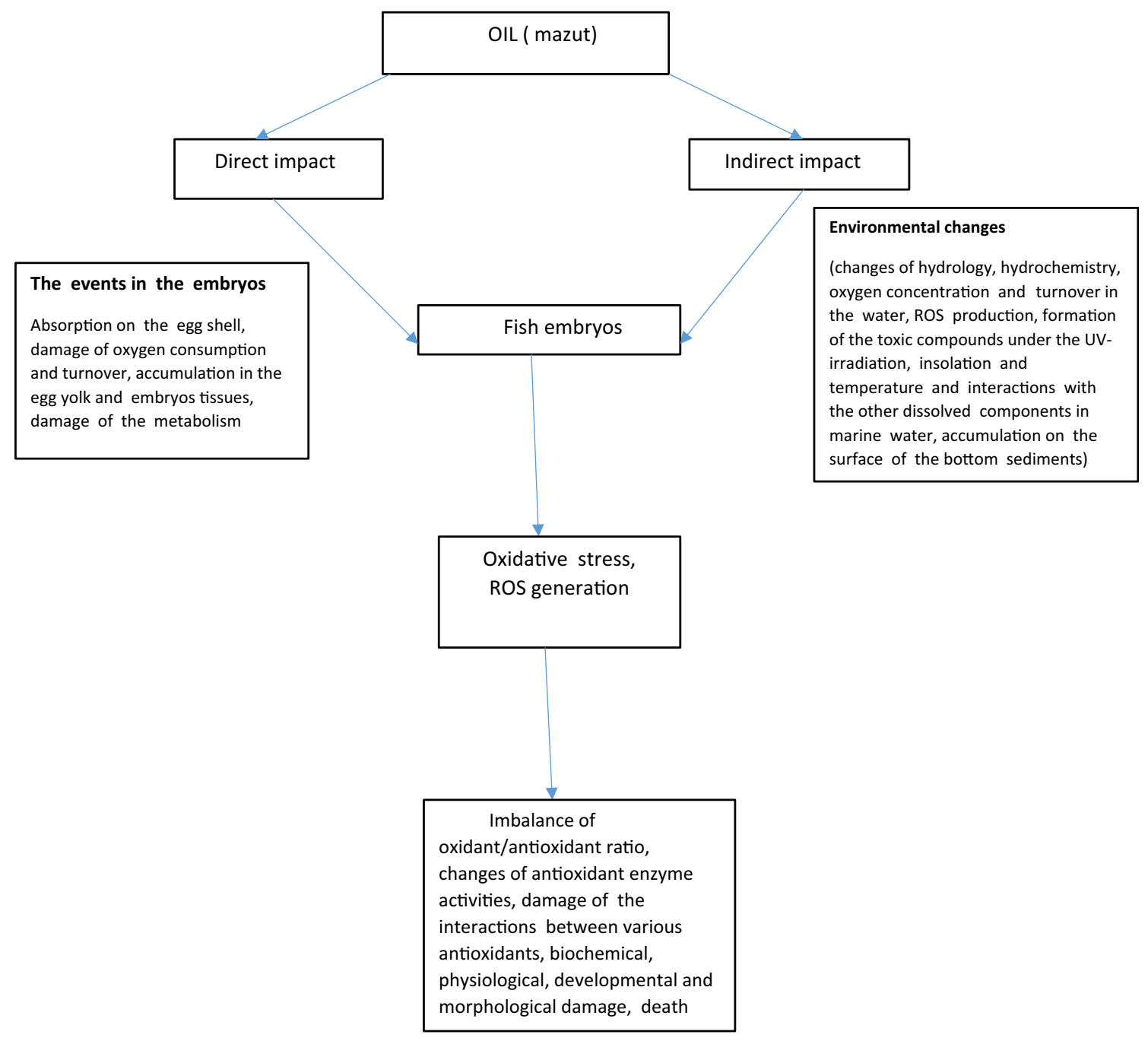

Fig. 3 The scheme of mazut toxicity on fish embryos

\section{Conclusions}

Biomarker variables in the fish embryos reported in this study seem to be useful indicators of oil toxicity and the health status of water quality in monitoring studies. The best biomarker is the PER activity, which was highly sensitive to oil pollution and reflects the response of the organism to stressful environment. The response of other tested antioxidant enzymes was not uniform and depended on embryonic developmental stage and mazut concentration. The response of biomarkers is not uniform and only measuring a battery of bioindicators can provide insight only into the fish health and ecological status of their habitats. The imbalance between tested antioxidant enzyme activities was clearer at low and high levels of mazut and it was less in the case of medium values. We could propose that low concentrations of mazut initiated antioxidant defense in developing fish embryos, at medium toxicant values, the response was relatively stable, and at high concentrations, it caused the inhibition of the enzyme activities and dissociation of interactions between them. The obtained results can be applied to the development of oil toxicity tests for monitoring management and for perspectives of conservation ecology

Acknowledgements The author wishes to thank Dr. T.L.Chesalina for help in experimental design. This study was supported by the Russian Foundation of Basic Research (Project no. 18-44-920007 "The role of global and local factors in the formation of ichthyoplanktonic communities in Black Sea"). 
Open Access This article is distributed under the terms of the Creative Commons Attribution 4.0 International License (http:// creativecommons.org/licenses/by/4.0/), which permits unrestricted use, distribution, and reproduction in any medium, provided you give appropriate credit to the original author(s) and the source, provide a link to the Creative Commons license, and indicate if changes were made.

\section{References}

Asatiani VS (1965) New methods of biochemical determinations. Nauka, Moscow (in Russian)

Bellas J, Beiras R, Marino-Balsa JC, Fernandez N (2005) Toxicity of organic compounds to marine invertebrate embryos and larvae: a comparison between sea urchin embryogenesis bioassay and alternative test species. Ecotoxicology 14:337-353

Cao L, Huang W, Liu J, Yin X, Dou Sh (2010) Accumulation and oxidative stress biomarkers in Japanese flounder larvae and juveniles under chronic cadmium exposure. Comp Biochem Physiol Part C Toxicol Pharmacol 151(3):386-392. https://doi. org/10.1016/j.cbpc.2010.01.004

Carpenter A, Kostianoy AG (2019) Oil pollution in the Black Sea. Springer, Berlin

Chesalina TL, Rudneva II, Kuzminova NS (2000) Toxic effects of diesel on the fry of Black Sea Liza saliens. Ichthyology 40(3):429-432 (in Russian)

Çokacar T (2008) The Eastern Mediterranean-Black Sea system with high oil spill risk. In: Davidson WF, Lee K, Cogswell A (eds) Oil spill response: a global perspective. NATO science for peace and security series C: environmental security. Springer, Dordrecht, pp 327-340. https://doi.org/10.1007/978-1-4020-8565-9_42

de Andrade Brito I, Garcia JRE, Salaroli AB, Figueira RCL, de Castro Martins C, Neto AC, Gusso-Choueri PK, Choueri RB, Borges S, Araujo L, de Oliveira Ribeiro CA (2018) Embryo toxicity assay in the fish species Rhamdia quelen (Teleostei, Heptaridae) to assess water quality in the Upper Iguaçu basin (Parana, Brazil). Chemosphere 208:207-218. https://doi.org/10. 1016/j.chemosphere.2018.05.009

Dechnik TV (1973) Black Sea Ichthyoplankton. Naukova Dumka, Kiev (in Russian)

Depledge M, Galloway TS (2015) Healthy animals, healthy ecosystems. Front Ecol Environ 3:251-258. https://doi.org/10.1890/ 1540-295(2005)003\%5b0251:HAHE\%5d2.0.CO;2

Domingyes I, Oliveira J, Lourenco J, Grisolia CK, Mendo S, Soares AMVM (2010) Biomarkers as a tool to assess effects of chromium (VI): comparison of responses in zebrafish early life stages and adults. Comp Biochem Physiol Part C Toxicol Pharmacol 152:338-345. https://doi.org/10.1016/j.cbpc.2010.05.010

Embry MR, Belanger SE, Braunbeck TA, Galay-Burgos M, Der Ha Lo M, Hinton DE, Leonard MA, Lillicrap A, Norberg-King T, Whale G (2010) The fish embryo toxicity test as an animal alternative method in hazard and risk assessment and scientific research. Aquat Toxicol 97:79-87. https://doi.org/10.1016/j.aquatox.2009.12.008

Farina O, Ramos R, Bastidas C, Carcia E (2008) Biochemical responses of cnidarian larvae to mercury and benzo(a)pyrene exposure. Bull Environ Contam Toxicol 81:553-557

Florin N, Ristea M, Cotorcea A (2015) Estimating the containment costs the situation of oil spill in the marine environment: case study: Romanian Black Sea coast. J Environ Protect Ecol 16(1):110-116

Franco EM, Felgenhauer BE, Klerks PL (2018) Crude oil toxicity to fiddler crabs (Uca longisignalis and Uca panacea) from the northern Gulf of Mexico: impacts on bioturbation, oxidative stress, and histology of the hepatopancreas. Environ Noxicol Chem 37(2):491-500. https://doi.org/10.1002/etc.3982

Geraudie P, Bakkemo R, Milinkovitch T, Tyomas-Guyon H (2016) First evidence of marine diesel effects on biomarker responses in the Icelandic scallops, Chlamys islandica. Environ Sci Pollut Res Int 23(16):6504-6512

Halafian AA (2008) Statistica. Binom Publ, Moscow

Hansen BH, Farkas J, Nordtug T, Altin D, Brakstad OG (2018) Does microbial biodegradation of water-soluble components of oil reduce the toxicity to early stages of fish? Environ Sci Ecol 162:59-62. https://doi.org/10.1021/acs.est.7b06408

Heintz RA, Short JW, Rice SD (1999) Sensitivity of fish embryos to weathered crude oil: Part II. Increased mortality of pink salmon (Oncorhynchus gorbuscha) embryos incubating downstream from weathered Exxon valdez crude oil. Environ Toxicol 18(3):494-503. https://doi.org/10.1002/etc.5620180318

Jiang M, Li L, Shen G, Shen X (2017) Oxidative stress in shellfish Sinonovacula constricta exposed to the water accommodated fraction of zero sulfur diesel oil and pinghu crude oil. Arch Environ Contamin Toxicol 73(2):294-300

Kalinina EM (1976) Spawning and development of Azov Sea and Black Sea gobies. Naukova Dumka, Kiev (in Russian)

Kuznetsov AN, Fedorov JuA (2010) The trends of distribution and transformation of oil pollution in the region of technogenic accident in Kerch Strait. Newsl Rus Geogr Soc 142(2):53-59 (in Russian)

Leonov AV, Fashuk DY (2006) Biotransformation of oil carbohydrates in Karkinite Bay in Black Sea: the evaluation as the result of mathematics simulation. Water Res 33(3):311-326 (in Russian)

Lesser MP (2006) Oxidative stress in Marine environment: biochemical and physiological ecology. Annu Rev Physiol 68:253-278

Litvin FF (1981) Laboratory manual of physicochemical methods in biology. Moscow State University, Moscow (in Russian)

Lowry OH, Rosebrough NJ, Farr AL, Randall R (1951) Protein measurement with the Folin-phenol reagent. J Biol Chem 193:165-175

Martin DJ, Adams J, Hollebone B, King Th, Brown SR, Hodson PV (2014) Chronic toxicity of heavy fuel oils to embryos using multiple exposure scenarios. Environ Toxicol Chem 33:677-687. https://doi.org/10.1002/etc.2486

Martinez-Gomez C, Campillo JA, Benedicto J, Fernandez B, Valdes J, Garcia I, Sanchz F (2006) Monitoring biomarkers in fish (Lepidorhombus boscii and Callionymus lyra) from the northern Iberian shelf after the Prestige oil spill. Mar Pollut Bull 53:305-314. https://doi.org/10.1016/j.marpolbul.2006.03.010 
Mu X, Pang S, Sun J, Gao J, Chen X, Chen X, Li X, Wang C (2013) Evaluation of acute and developmental effects of difenoconazole via multiple stage zebrafish assays. Environ Pollut 175:147-157. https://doi.org/10.1016/j.envpol.2012.12. 029

Mu X, Liu J, Yang K, Huang Y, Li X, Yang W, Oi S, Tif W, Shen G, Li Y (2018) 0\#Diesel water-accommodated fraction induced lipid homeostasis alteration in zebrafish embryos. Environ Pollut 242(4):52-961. https://doi.org/10.1016/j.envpol.2018.07. 055

Nishikimi M, Rao NA, Yagik K (1972) The occurrence of superoxide anion in the reaction of reduced Phenazine. Biochem Biophys Res Commun 46(2):849-854

Oguz T (2017) Controls of multiple stressors on the Black Sea Fishery. Front Mar Sci 4:1-12. https://doi.org/10.3389/fmars.2017. 00110 (Article 110)

Patin SA (2015) Marine oil-gas complex: the sources and factors of ecological risk. Protect Environ Oil Gas Complex 4:5-12 (in Russian)

Pauka LM, Maceno M, Silva Rossi, de Assis SC (2011) Embryotoxicity and biotransformation responses in zebrafish exposed to water-soluble fraction of crude oil. Bull Environ Contam Toxicol 86:389-393

Pereira TM, Merçon J, Passos LS, Coppo GC, Lopes TOM, Cabral DS, Scherer R, Chippari-Gomes A (2018) Effects of the watersoluble fraction of diesel oil (WSD) on the fertilization and development of a sea urchin (Echinometra lucunter). Ecotoxicol Environ Saf 162:59-62. https://doi.org/10.1016/j.ecoenv.2018.06.040

Pereslegina IA (1989) Antioxidant enzyme activity of the saliva of the healthy children. Lab Methods 11:20-23 (in Russian)

Rudneva II (1999) Antioxidant system of Black Sea animals in early development. Comp Biochem Physiol C 122(2):265-271

Rudneva II (2014) Biomarkers for stress in fish embryos and larvae. CRC Press, Taylor \& Francis Group, Boca Raton

Rudneva I, Petzold-Bradley E (2001) Environment and security challenges in the Black Sea region. In: Petzold-Bradley E, Carius A, Vincze A (eds) Responding to environmental conflicts: implications for theory and practice. NATO Science Series (Series 2. Environmental Security), 1 78. Springer, Dordrecht, pp 189-207. https://doi.org/10.1007/978-94-010-0395-7_12

Rudneva II, Boltachev AR, Karpova EP, Kovyrshina TB, Skuratovskaya EN, Chesnokova II (2016) Gobiidae species in Black Sea estuaries and Bays: biodiversity, health status and conservation. In: Martinez EK (ed) Coastal fishes: habitat, behavior and conservation. Nova Science Publishers, New York, pp 69-124

Sardi AE, Renaud PE, Morais GC, Martins CC, da Cunha Lana P, Camus L (2017) Effects of an in situ diesel oil spill on oxidative stress in the clam Anomalocardia flexuosa. Environ Pollut 230:891-901. https://doi.org/10.1016/j.envpol.2017.07.04

Sarkar A, Ray D, Shrivastava AN, Sarker S (2006) Molecular biomarkers: their significance and application in marine pollution monitoring. Ecotoxicology 15:333-340

Van der Oost R, Beyer J, Vermeulen NBE (2003) Fish bioaccumulation and biomarkers in environmental risk assessment: a review. Environ Toxicol Pharmacol 13(3):57-149. https://doi.org/10.1016/S1382-6689(02)00126-6

Zhang JF, Wang XR, Guo HY, Wu C, Xue YQ (2004) Effects of water-soluble fractions of diesel oil on the antioxidant defenses of the goldfish Carassius auratus. Ecotoxicol Environ Saf 58:110-116. https://doi.org/10.1016/j.ecoenv.2003.08.025

\section{Publisher's Note}

Springer Nature remains neutral with regard to jurisdictional claims in published maps and institutional affiliations. 